\title{
Retrospective voting on the party level: An Icelandic test
}

This research note adds to the emerging body of literature arguing that retrospective voting works on the level of political parties - for government and opposition parties alike - by investigating the generalisability of previous findings. Furthermore, it tests whether there is a knowledge-gap in retrospective voting on the party level. Using the data of the Icelandic National Election Study (ICENES), I find support for the argument that mechanisms of electoral accountability work both for incumbent and opposition parties. Second, while previous research raised doubts on the electorate's ability to hold governments accountable, there is no evidence of a knowledge-gap in retrospective voting on the party level.

Keywords: Retrospective voting, electoral accountability, political knowledge, performance voting, political parties 


\section{Retrospective voting on the level of political parties}

The retrospective voting theory states that voters retrospectively evaluate the government's performance and decide which party to vote for based on this evaluation: if voters are satisfied, they will reward the government by voting for an incumbent party, while dissatisfied voters will punish the incumbent by supporting the opposition (Kramer, 1971). Doing so, voters hold incumbent parties accountable for their performance (Przeworski, Stokes, \& Manin, 1999), and these parties need to take the voters' interests into account under penalty of being voted out of office.

Traditionally, retrospective voting has mainly focused on the basic distinction between "the government" and "the opposition", explaining why voters would switch from an incumbent party to an opposition party or vice versa (Stiers, forthcoming). This view has been challenged, however, as research on the theory expanded to countries with complex multiparty systems. In these contexts, scholars examined individual governing parties i.e., whether and how the effect of retrospective performance evaluations varies between coalition partners (Anderson, 2000). These studies found that voters are able to distinguish different coalition partners; Plescia (2017), for instance, shows that, in general, it is mainly the party of the Prime Minister that is held responsible for the government's performance, and that responsibility attributions of other incumbent parties decrease by party size in the parliament (see also Debus, Stegmaier, \& Tosun, 2014).

More recently, then, research took the next step by investigating the effect of retrospective performance evaluations on the vote for all parties - taking into account parties in opposition as well (Debus et al., 2014; Plescia \& Kritzinger, 2017; Söderlund, 2008; Stiers, forthcoming). These studies argue that opposition parties can be evaluated for how they run in opposition, and that these evaluations influence their electoral success following the same reward-punishment mechanism as incumbent parties. Although this 
argument was already made by (Przeworski et al., 1999, p. 44), stating that, in making up their party choice, '(...) voters use the information about the past performance of the incumbent and, if available, of challengers' (emphasis added), until recently this reference to "the challengers" has received remarkably little attention in empirical analyses of retrospective voting.

Admittedly, opposition parties cannot be evaluated on their performance in office, as they do not hold executive power. However, opposition parties have their own specific role of running in opposition, and they can, for instance, openly criticise the government and emphasise certain issues (Vavreck, 2009). Furthermore, while the executive power lies with the government, in some situations the approval of opposition parties might be necessary to pass legislation (Plescia \& Kritzinger, 2017). ${ }^{1}$

Before presenting the evidence previous studies have offered for this hypothesis, it is important to note that I do not argue that the proposed mechanism on the party level replaces the "traditional" model. The traditional retrospective voting model has proved its value in explaining voter's choices, but also has some gaps - for instance, once a voter decided not to vote for a government party, how does she decide which opposition party

\footnotetext{
${ }^{1}$ Note that the evaluation of opposition parties could be a function of the evaluation of the government as well - i.e., if a voter evaluates the government positively, she might be less likely give opposition parties a positive evaluation. (I thank the anonymous reviewer for suggesting this possibility.) There are, then, substantial positive correlations between the evaluations of government parties and opposition parties respectively, and negative correlations between the evaluations of the government and opposition parties. However, performance evaluations of the opposition parties help explaining why opposition voters chose one opposition party over another - which seems to support the argument presented here. This is not conclusive evidence, however, and later research could investigate explicitly in what the evaluations of government and opposition originate.
} 
to vote for? The theory of retrospective evaluations on the party-level proposes a complementary mechanism that aims to fill these gaps.

\section{The empirical evidence}

Two recent contributions to the literature on retrospective voting explicitly investigate the effect of party-level performance evaluations on the vote for all parties. First, using the data of the German Longitudinal Election Study (GLES), Plescia and Kritzinger (2017) show that voters evaluate the performance of parties in government and opposition, and that these party-level evaluations influence the vote for all parties. As could be expected, the trade-off in which a positive effect for one party is paralleled by a negative effect for the other parties is strongest between the main incumbent party and the main opposition party.

Second, Stiers (forthcoming) places the results of Plescia and Kritzinger (2017) in a cross-national perspective by using the data of the second module of the Comparative Study of Electoral Systems (CSES). Using performance evaluations of the party the respondent voted for in the last election, he shows that voters who are satisfied with the performance of their party are more likely to vote for this party again than what holds for dissatisfied voters, and that this result is significant controlling for satisfaction with the government's performance as well. Furthermore, this result holds in all groups of voters: irrespective of whether a voter previously voted for an incumbent or an opposition party, satisfaction with the performance of the party one previously voted for increases the probability of voting for this party again.

These previous studies have found strong evidence supporting the argument that retrospective voting also works on the level of political parties. However, they have only been able to provide tentative evidence of the generalisability of this finding. The study of 
Plescia and Kritzinger (2017) remains limited to the German context, so it is unclear whether or not their findings are determined by characteristics of this context specifically. The study of Stiers (forthcoming) can only use the evaluation of the performance of the party the voter voted for in the last election - not for each party that was running in the election.

The Icelandic National Election Study (ICENES, 2013) includes performance evaluations for every party that had seats in the Parliament before the election. ${ }^{2}$ Using these data, this note aims to provide a crucial piece of evidence for the generalisability of the findings of previous studies, as it can reveal whether or not previous indications of generalisability are warranted using better suited data. While finding the mechanism to work in Iceland would not provide full proof of its generalisability to other contexts beyond Germany and Iceland, it would rule out that that the results of previous research were determined by characteristics of one specific context or the use of imperfect data.

\section{Retrospective voting and political knowledge}

While previous studies indicated the existence of mechanisms of retrospective voting on the level of political parties, these studies did not take into account possible sources of heterogeneity in the effect of retrospective performance evaluations on the vote. One resonating finding from the "traditional" model of retrospective voting is that voters need to hold sufficient information to hold governments accountable at the polls (de Vries \& Giger, 2014). More knowledgeable voters are better able to hold and process this information, and hence to credit and blame incumbent parties for their performance. This implies that rewarding and punishing incumbent parties is limited to a highly-informed

\footnotetext{
${ }^{2}$ I thank Christian Schimpf for pointing me to the availability of these data.
} 
part of the electorate, and political parties could hence afford to be responsive to a small part of the electorate only (de Vries \& Giger, 2014).

However, it is unclear whether retrospective voting on the party level suffers from the same knowledge gap. In this view on retrospective voting, voters are expected to evaluate the performance of all parties, and even though they are no longer required to correctly identify the incumbent parties, this could be expected to require even more information. On the other hand, rather than following the government's policies and their outcomes, it suffices for voters to have a general opinion on the performance of every party. Hence, it remains an open question whether and to what extent political knowledge moderates retrospective voting on the level of political parties as well.

\section{Data and methods}

In this study, the data of the Icelandic National Election Study 2013 are used (Harðarson, Pórisdóttir, \& Önnudóttir, 2013). These data consist of telephone surveys conducted in the weeks after the election of 27 April 2013. It includes voters living in Iceland aged between 18 and 80 years old, and the response rate amounted to $59.3 \%$.

Iceland constitutes an ideal setting to test the mechanism of retrospective voting on the party level. Traditionally, Iceland had a stable party system consisting of four parties, usually complemented with some short-lived smaller parties (for more discussion on the Icelandic setting, and recent elections more specifically, see Önnudóttir, Schmitt, \& Harðarson (2017)). In the election preceding the election under investigation - in $2009-$ the longstanding dominance of the right-winged Independence Party was broken, as it was punished for the financial crisis (Indriðason, Önnudóttir, Pórisdóttir, \& Harðarson, 2017; Önnudóttir \& Harðarson, 2011; Önnudóttir et al., 2017). This gave rise to a new coalition between the left-wing Social Democratic Alliance and Left-Green Movement. However, 
in the 2013 election, the Independence Party regained governmental control - one election after having been punished severely. Hence, after the trend-breaking results in the 2009 elections, in 2013 the traditionally strongest party - in opposition during this term regained control, while the traditional opposition parties that were responsible for economic recovery were voted out of office again. As Indriðason et al. (2017, p. 50) state, this makes the 2013 election a very peculiar and interesting case: 'In that election, the two parties that were blamed the most for the economic crisis won majority, while the two left parties, which had been in power for one term during which the economy had improved substantially, lost the election.' Furthermore, their study indicates that the opposition parties' success in the 2013 election was at least partly due to their successful strategy to set the issue agenda (Indriðason et al., 2017). Hence, the 2013 Icelandic election makes for an exemplary case to investigate the importance of evaluations of opposition parties in voters' decisions which party to vote for.

In the ICENES survey, respondents were asked to evaluate the performance of all parties that were represented in the Parliament: 'Next questions are about the performance of all the political parties that were represented in Althingi in the last electoral term (from 2009 to 2013). How good or bad a job do you consider that each party did during that term? Has it done a very good job? A good job? A bad job? A very bad job?' The answer categories were reversed so that higher values indicate more positive evaluations.

This question was asked for all parties that were represented in the Parliament during the term 2009-2013. In 2009, seven parties competed in the election, and five parties won Parliamentary seats. Of these five parties, one party (Civic Movement) dissolved during the term, and this will make for a test of the effect of performance evaluations of a party that does not run in the election on the vote for other parties. In the 2013 election, fifteen parties competed. However, less than five percent of the respondents indicated to have voted for one of the new parties respectively, and this number is too small to be included 
in the analyses. The only exception is the party 'Bright Future' (6.69\% of the respondents indicated to have voted for this party) that will be included in the analyses. As it is a new party, there is no performance evaluation available for Bright Future, and this will make for a test of the effect of evaluations of the performance of the government and other parliamentary parties on the vote for a new party.

Following Plescia and Kritzinger (2017), multinomial logistic regression models are estimated with controls for sex ( $1=$ female), age, satisfaction with the way democracy works in Iceland, political interest, and party identification with each of the respective parties. More details of the variables in the analyses, as well as descriptive statistics, are included in Appendix A. Three models are estimated; first, the traditional retrospective voting model is estimated - including the evaluation of the government's performance. Second, the evaluation of the performance of each party is included in the model as well. Finally, these evaluations are interacted with political knowledge. Political knowledge is a scale denoting the number of correct answers to four factual questions. ${ }^{3}$ For each question, respondents could choose between four options. Respondents refusing to answer and don't knows are coded as wrong answers.

\section{Results}

First, the traditional retrospective voting mechanism is tested. To allow for meaningful interpretation of the coefficients, the attention here is on their substantive effect sizes in terms of changes in predicted probabilities, while the full regression tables are included in

\footnotetext{
${ }^{3}$ The questions were: (1) Which of these persons was the Finance Minister before the recent election?; (2) What was the current unemployment rate in Iceland as of the end of March 2013. Was it...; (3) Which party came second in votes in the election to Althingi?; (4) Who is the current Secretary-General of the United Nations?
} 
Appendix B. Hence, Figure 1 displays the average marginal effect of performance evaluations on the vote for the five main parties running in the election.

Figure 1: Average marginal effects of government evaluations on the vote.

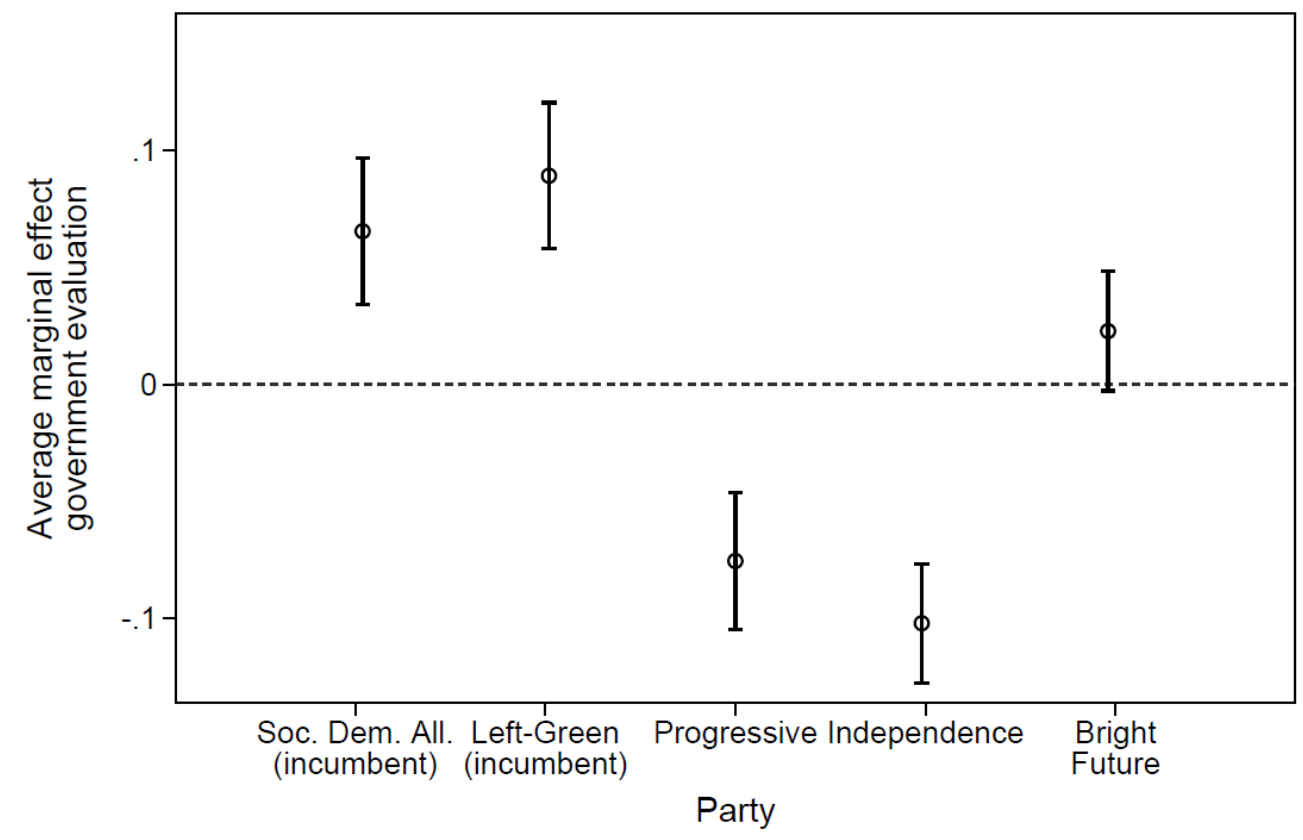

Note: the figure shows the average marginal effect and 95\% confidence intervals of retrospective performance evaluations of the government based on the results presented in Model 1 in Table 3 in Appendix B.

The results displayed in Figure 1 show that voters who are satisfied with the government's performance will be more likely to vote for an incumbent party. For every one-unit increase in satisfaction with the government, there is an average increase of 6.55 percentage points in the probability of voting for the Social Democratic Alliance, and 8.92 percentage points for the Left-Green Movement. As the theory would predict, there is a negative effect of government satisfaction on voting for an opposition party. Interestingly, there is no significant effect of satisfaction with the government on voting for the new party - Bright Future. It needs to be noted, however, that the coefficient is close to reaching 
statistical significance $(\mathrm{p}=0.08)$, and that the proportion of voters for Bright Future in the estimation sample is very small $(8.93 \%, \mathrm{n}=59)$.

Second, the performance evaluations of all parties are included in the model. ${ }^{4} \mathrm{~A}$ first interesting observation is that the model that includes party-level evaluations has a better model fit (i.e., the pseudo- $R^{2}$ increases from 0.45 to 0.56 , and a Likelihood Ratio tests indicates that this difference is significant, with $\mathrm{p}<0.001)$. Figure 2 displays the average marginal effects of the evaluation of each party on the vote for each party respectively.

Figure 2: Average marginal effects of party-level evaluations on the vote.
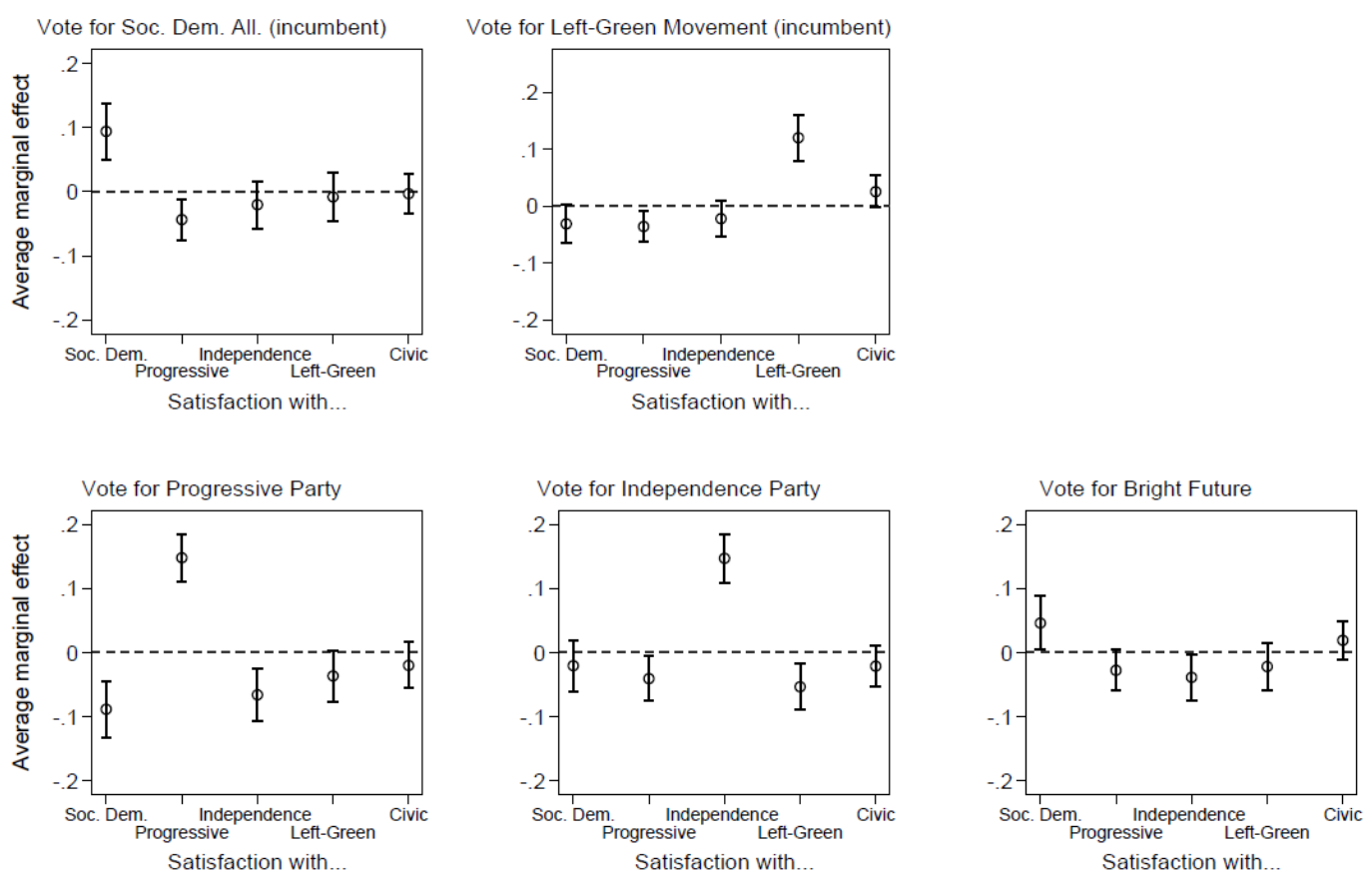

Note: the figure shows the average marginal effect and 95\% confidence intervals of retrospective performance evaluations of each party respectively based on the results presented in Table 3 in Appendix B.

\footnotetext{
${ }^{4}$ Note that the reference category for the multinomial models is a vote for the Social Democratic Alliance, and the coefficients presented in the Tables should hence be interpreted accordingly. However, the results presented in the Figures show the effect of the respective party versus all other parties, so do not depend on the chosen reference category.
} 
The results displayed in Figure 2 are consistent with the theory. First, overall, being satisfied with the performance of a party has a strong positive effect on the probability of voting for this party. The only exception is the evaluation of the Civic Movement; satisfaction with a party that ceases to exist does not seem to influence voting behaviour for other parties. Furthermore, regarding Bright Future, the only significant results are for the Social Democratic Alliance (positive) and the Independence Party (negative). Overall, however, these effects are small, and the fact that there are no strong results for a party that dissolves or a new party shows strong support for the argument that retrospective voting works for political parties specifically.

Furthermore, the results also show that satisfaction with the performance of certain parties decreases the probability of voting for some other parties, but there do not seem to be consistent patterns between incumbent and opposition parties, or according to the relative size of the different parties. ${ }^{5}$ This constitutes strong evidence for retrospective voting on the party level: it seems that voters evaluate each party, and this evaluation feeds in their party choice for all parties alike. Moreover, further evidence comes from the fact that more positive evaluations of the performance of an opposition party decreases the probability of voting for some other opposition parties (e.g. Progressive Party versus Independence Party). This seems to indicate that voters evaluate parties specifically, rather than perceptions of the performance of opposition parties being determined by the evaluation of the government's performance.

Finally, interactions between political knowledge and party evaluations are included in the model. The full results are summarised in Table 2 in Appendix B. If there is a knowledge gap, it is most likely to manifest itself in the effect of satisfaction with a party

\footnotetext{
${ }^{5}$ In this case, the largest incumbent party was the Social Democratic Alliance, and the main opposition party was the Independence Party.
} 
on the vote for that party. Therefore, Figure 3 displays the effects of satisfaction with the respective party, at different levels of political knowledge, on the vote for that party. As there is no evaluation of the new party Bright Future, it is not included in the Figure. ${ }^{6}$

The results displayed in Figure 3 seem to be mixed. While there is no evidence of a knowledge gap in the vote for the Progressive Party and the Independence Party, it seems like the effect of retrospective evaluations on the vote is larger at higher levels of political knowledge for the two incumbent parties. However, the differences between the different levels of political knowledge are not significant. ${ }^{7}$ The only substantial difference seems to found among voters of the Social Democratic Alliance: even though the difference between low- and high-knowledgeable voters is not statistically significant, there is no evidence for an effect of retrospective performance evaluations on the vote for lowknowledgeable voters, while there is a substantial effect among high-knowledgeable voters. ${ }^{8}$

\footnotetext{
${ }^{6}$ As the main interest is in the conditional effects of performance evaluations, only the effects of the evaluations of the parties themselves are reported here. However, parallel negative effects could be expected for other parties. Therefore, to provide a full overview of the conditional effects of satisfaction with all parties on the vote for every party respectively, Figure 1 in Appendix B displays the effects of all coefficients reported in Model 3 in Table 2.

${ }^{7}$ It is admittedly difficult to interpret coefficients of a multinomial regression model. However, also modelling the choice for the Social Democratic Alliance and the Left-Green Movement respectively, the interaction coefficients do not reach statistical significance. As a less stringent test, the models were also estimated including only the relevant interaction (i.e., political knowledge interacted with the performance evaluation of the respective party), and also these models did not reveal any significant interactions.

${ }^{8}$ Note that the same conclusion arises looking at the model fit statistics. The model fit increases significantly between Model 1 and Model 2 (p-value lr-test<0.001). However, although the pseudo-R2 increases slightly for Model 3, the difference with Model 2 is not significant ( $\mathrm{p}=0.740)$. Hence, this also seems to support the conclusion that adding interactions with political knowledge does not add to explaining the vote.
} 
Figure 3: Average marginal effects of party-level evaluations on the vote at different levels of political knowledge.
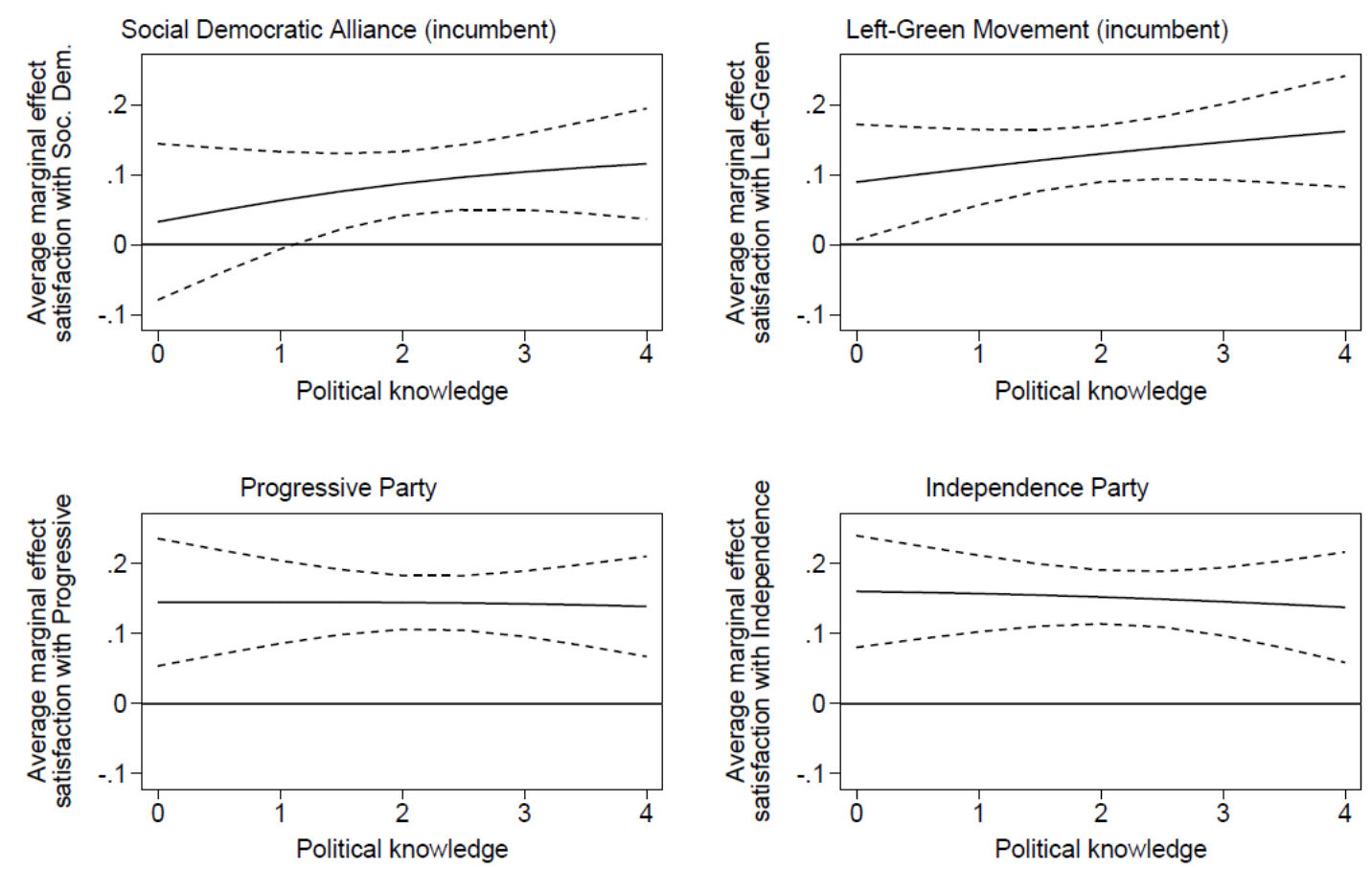

Note: the figure shows the average marginal effect and 95\% confidence intervals of retrospective performance evaluations at different levels of political knowledge, based on the results presented in Table 3 in Appendix B.

To put the results to the test, I also replicated the models of Stiers (forthcoming). The findings, reported in Appendix C, are in line with the conclusions presented here. 


\section{Conclusion}

This note contributes to the body of literature investigating the impact of party-level performance evaluations on the vote. In line with previous research findings, the results show that retrospective performance evaluations of political parties help explaining the vote for these parties - irrespective of whether this party was in government or in opposition. Hence, these findings lend support to the generalisability and wider applicability of the claim that retrospective voting works on the level of political parties as well. Furthermore, the results show no significant interaction effect with political knowledge, indicating that all voters punish and reward political parties for their performance to the same extent.

An important limitation of the study that needs to be taken into account, however, is that it is very difficult to distinguish voters' performance evaluations of a certain party from their general feelings towards that party - i.e., the performance evaluations could be tapping into a general preference towards certain parties. Furthermore, as is the case in traditional retrospective voting models, there might be an endogenous relationship between party evaluations and the vote. Although Stiers (forthcoming) shows in a robustness test that the effects of party-level performance evaluations remain when controls are included for the extent to which the voter "likes" the different parties, and even though controls are included for party identification, it is reasonable to assume that the coefficients reported here are at least partly biased upwards. 


\section{References}

Anderson, C. J. (2000). Economic voting and political context: A comparative perspective. Electoral Studies, 19(2), 151-170.

Debus, M., Stegmaier, M., \& Tosun, J. (2014). Economic Voting under Coalition Governments: Evidence from Germany. Political Science Research and Methods, 2(1), 49-67.

de Vries, C. E., \& Giger, N. (2014). Holding Governments Accountable? Individual Heterogeneity in Performance Voting. European Journal of Political Research, 53(2), 345-362.

Harðarson, Ó. P., Pórisdóttir, H., \& Önnudóttir, E. H. (2013). Icelandic National Election Study (ICENES). http://fel.hi.is/2013_0.

Indriðason, I. H., Önnudóttir, E. H., Pórisdóttir, H., \& Harðarson, Ó. P. (2017). Re-electing the Culprits of the Crisis? Elections in the Aftermath of a Recession. Scandinavian Political Studies, 40(1), 28-60.

Kramer, G. H. (1971). Short-Term Fluctuations in U.S. Voting Behavior, 1896-1964. American Political Science Review, 65(1), 131-143.

Önnudóttir, E. H., \& Harðarson, Ó. P. (2011). Policy Performance and Satisfaction with Democracy. Icelandic Review of Politics \& Administration, 7(2), 417.

Önnudóttir, E. H., Schmitt, H., \& Harðarson, Ó. P. (2017). Critical Election in the Wake of an Economic and Political Crisis: Realignment of Icelandic Party Voters? Scandinavian Political Studies, 40(2), 157-181.

Plescia, C. (2017). Portfolio-Specific Accountability and Retrospective Voting: The Case of Italy. Rivista Italiana di Scienza Politica, 47(3), 313-336.

Plescia, C., \& Kritzinger, S. (2017). Retrospective Voting and Party Support at Elections: Credit and Blame for Government and Opposition. Journal of Elections, Public Opinion and Parties, 27(2), 156-171. 
Przeworski, A., Stokes, S. C., \& Manin, B. (Eds.). (1999). Democracy, Accountability, and Representation. Cambridge: Cambridge University Press.

Söderlund, P. (2008). Retrospective Voting and Electoral Volatility: A Nordic Perspective. Scandinavian Political Studies, 31(2), 217-240.

Stiers, D. (forthcoming). Beyond the Distinction Incumbent-Opposition: Retrospective Voting on the Level of Political Parties. Party Politics, accepted.

Vavreck, L. (2009). The Message Matters: The Economy an Presidential Campaigns. Princeton: Princeton University Press. 


\section{Appendices}

\section{Appendix A: Variables in the analyses}

- Sex: Sex of the respondent. Code $0=$ female (reference category); code $1=$ male.

- Age: Age of the respondent at the moment of interview.

- Satisfaction with democracy: Answer to the question: 'On the whole, are you very satisfied, fairly satisfied, not very satisfied, or not at all satisfied with the way democracy works in Iceland?' The scale was reversed so that higher numbers denote a higher satisfaction with democracy.

- Political interest: Answer to the question: 'Do you consider your interest in politics very great, great, some, little, or are you not interested in politics at all?' The scale was reversed so that higher numbers denote a higher level of interest in politics.

- Political knowledge: The amount of correct answers on four factual questions. The questions were:

- Which of these persons was the Finance Minister before the recent election?

- What was the current unemployment rate in Iceland as of the end of March 2013? Was it...

- Which party came second in votes in the election to Althingi?

- Who is the current Secretary-General of the United Nations?

For each question, respondents could choose from four answer-categories. Respondents refusing to answer and don't knows are coded as wrong answers.

- Party identification: First, respondents were asked: 'Many people consider themselves supporters of political parties while others do not feel solidarity with any party. Do you in general consider yourself as a supporter of any political party or 
organisation?'. Respondents could answer with "yes" or “no". Those answering no were subsequently asked: 'Do you nevertheless feel somewhat closer to any party or organisation than to others?' Again, respondents could answer whether or not they feel closer to a party. Respondents answering "yes" on one of the two questions were subsequently asked 'what party is that?' Respondents receive code 1 as identifying with a certain party if they mention that party, and code 0 otherwise.

- Performance evaluation parties: Respondents were told: 'Next questions are about the performance of all the political parties that were represented in Althingi in the last electoral term (from 2009 to 2013). How good or a bad job do you consider that each party did during that term?' Subsequently, all parties were probed in a random order, and respondents could indicate whether the performance of the party was 'very good', 'somewhat good', 'somewhat bad', or 'very bad'. The scale was reversed so that higher numbers denote a better performance evaluations. 
Table 1: Descriptive statistics of the variables in the analyses

\begin{tabular}{lcccc}
\hline \hline Variable & Mean & Std. Dev. & Minimum & Maximum \\
\hline Sex & 0.407 & 0.492 & 0 & 1 \\
Age & 48.820 & 14.958 & 18 & 80 \\
Satisfaction democracy & 1.702 & 0.714 & 0 & 3 \\
Political interest & 2.396 & 0.916 & 0 & 4 \\
Political knowledge & 2.345 & 1.077 & 0 & 4 \\
PID Soc. Dem. All. & 0.082 & 0.274 & 0 & 1 \\
PID Progressive & 0.080 & 0.272 & 0 & 1 \\
PID Independence & 0.213 & 0.410 & 0 & 1 \\
PID Left Green & 0.059 & 0.236 & 0 & 1 \\
PID Bright Future & 0.003 & 0.055 & 0 & 1 \\
Performance Soc. Dem. All. & 1.433 & 0.879 & 0 & 3 \\
Performance Progressive & 1.501 & 0.787 & 0 & 3 \\
Performance Independence & 1.233 & 0.784 & 0 & 3 \\
Performance Left Green & 1.300 & 0.850 & 0 & 3 \\
Performance Bright Future & 1.056 & 0.777 & 0 & 3 \\
\hline \hline
\end{tabular}




\section{Appendix B: Full tables of the results presented in the text}

Table 2: Multinomial logistic regression models explaining party choice

\begin{tabular}{|c|c|c|c|c|c|c|}
\hline \multirow{3}{*}{$\begin{array}{l}\text { Ref.: Vote Social } \\
\text { Democratic Alliance }\end{array}$} & \multicolumn{3}{|c|}{ Progressive Party } & \multicolumn{2}{|c|}{ Independence Party } & \multirow[b]{2}{*}{ (3) } \\
\hline & (1) & (2) & (3) & (1) & (2) & \\
\hline & $\begin{array}{l}\text { B } \\
\text { (s.e.) }\end{array}$ & $\begin{array}{l}\text { B } \\
\text { (s.e.) }\end{array}$ & $\begin{array}{l}\text { B } \\
\text { (s.e.) }\end{array}$ & $\begin{array}{l}\text { B } \\
\text { (s.e.) }\end{array}$ & $\begin{array}{l}\text { B } \\
\text { (s.e.) }\end{array}$ & $\begin{array}{l}\text { B } \\
\text { (s.e.) }\end{array}$ \\
\hline Sex (ref.=male) & $\begin{array}{l}-0.547 \\
(0.349)\end{array}$ & $\begin{array}{l}-0.702 \\
(0.421)\end{array}$ & $\begin{array}{l}-0.710 \\
(0.426)\end{array}$ & $\begin{array}{l}-0.487 \\
(0.380)\end{array}$ & $\begin{array}{l}-0.707 \\
(0.464)\end{array}$ & $\begin{array}{l}-0.766 \\
(0.473)\end{array}$ \\
\hline Age & $\begin{array}{l}-0.020 \\
(0.011)\end{array}$ & $\begin{array}{l}-0.008 \\
(0.013)\end{array}$ & $\begin{array}{l}-0.010 \\
(0.013)\end{array}$ & $\begin{array}{l}-0.019 \\
(0.013)\end{array}$ & $\begin{array}{l}-0.011 \\
(0.015)\end{array}$ & $\begin{array}{l}-0.011 \\
(0.015)\end{array}$ \\
\hline Satisfaction democracy & $\begin{array}{c}0.086 \\
(0.243)\end{array}$ & $\begin{array}{l}-0.013 \\
(0.309)\end{array}$ & $\begin{array}{l}-0.003 \\
(0.315)\end{array}$ & $\begin{array}{l}0.666^{*} \\
(0.274)\end{array}$ & $\begin{array}{c}0.541 \\
(0.338)\end{array}$ & $\begin{array}{c}0.525 \\
(0.345)\end{array}$ \\
\hline Political interest & $\begin{array}{c}-0.574 * * \\
(0.206)\end{array}$ & $\begin{array}{l}-0.613^{*} \\
(0.240)\end{array}$ & $\begin{array}{l}-0.622 * \\
(0.246)\end{array}$ & $\begin{array}{l}-0.180 \\
(0.220)\end{array}$ & $\begin{array}{l}-0.206 \\
(0.254)\end{array}$ & $\begin{array}{l}-0.214 \\
(0.261)\end{array}$ \\
\hline Political knowledge & $\begin{array}{c}0.093 \\
(0.162)\end{array}$ & $\begin{array}{l}-0.012 \\
(0.187)\end{array}$ & $\begin{array}{l}0.070 \\
(0.600)\end{array}$ & $\begin{array}{l}0.189 \\
(0.180)\end{array}$ & $\begin{array}{c}0.156 \\
(0.208)\end{array}$ & $\begin{array}{c}0.837 \\
(0.624)\end{array}$ \\
\hline PID Soc. Dem. Alliance & $\begin{array}{c}-18.918 \\
(1703.504)\end{array}$ & $\begin{array}{l}-20.321 \\
(2843.428)\end{array}$ & $\begin{array}{c}-29.875 \\
(3.309 \mathrm{e}+05)\end{array}$ & $\begin{array}{l}-3.661 * * \\
(1.118)\end{array}$ & $\begin{array}{l}-4.753 * * \\
(1.767)\end{array}$ & $\begin{array}{l}-4.786^{*} \\
(1.876)\end{array}$ \\
\hline PID Progressive Party & $\begin{array}{c}17.091 \\
(1022.020)\end{array}$ & $\begin{array}{c}16.924 \\
(965.834)\end{array}$ & $\begin{array}{c}26.203 \\
(1.031 \mathrm{e}+05)\end{array}$ & $\begin{array}{c}-0.452 \\
(1312.097)\end{array}$ & $\begin{array}{c}-0.974 \\
(1418.970)(\end{array}$ & $\begin{array}{c}-1.110 \\
1.444 \mathrm{e}+05)\end{array}$ \\
\hline PID Independence Party & $\begin{array}{c}0.265 \\
(0.887)\end{array}$ & $\begin{array}{l}-0.852 \\
(0.999)\end{array}$ & $\begin{array}{l}-0.811 \\
(0.988)\end{array}$ & $\begin{array}{c}3.602 * * * \\
(0.781)\end{array}$ & $\begin{array}{l}2.436^{* *} \\
(0.881)\end{array}$ & $\begin{array}{l}2.474 * * \\
(0.872)\end{array}$ \\
\hline PID Left Green Movement & $\begin{array}{c}0.023 \\
(1.568)\end{array}$ & $\begin{array}{l}1.298 \\
(1.565)\end{array}$ & $\begin{array}{l}1.358 \\
(1.590)\end{array}$ & $\begin{array}{l}-16.193 \\
(2760.902)\end{array}$ & $\begin{array}{l}-16.058 \\
(5049.810)\end{array}$ & $\begin{array}{c}-24.635 \\
(5.196 \mathrm{e}+05)\end{array}$ \\
\hline PID Bright Future & $\begin{array}{c}1.361 \\
(2.799 \mathrm{e}+05)\end{array}$ & $\begin{array}{l}3.708 \\
(9.782 \mathrm{e}+05)\end{array}$ & $\begin{array}{c}4.030 \\
(1.170 \mathrm{e}+08)\end{array}$ & $\begin{array}{l}1.494 \\
(2.673 \mathrm{e}+05)\end{array}$ & $\begin{array}{c}2.644 \\
(9.472 \mathrm{e}+05)\end{array}$ & $\begin{array}{c}2.849 \\
(1.160 \mathrm{e}+08)\end{array}$ \\
\hline Performance government & $\begin{array}{l}-1.519 * * * \\
(0.265)\end{array}$ & $\begin{array}{c}0.110 \\
(0.369)\end{array}$ & $\begin{array}{c}0.122 \\
(0.376)\end{array}$ & $\begin{array}{l}-2.014 * * * \\
(0.279)\end{array}$ & $\begin{array}{l}-0.264 \\
(0.383)\end{array}$ & $\begin{array}{l}-0.275 \\
(0.393)\end{array}$ \\
\hline Performance Soc. Dem. & & $\begin{array}{c}-2.166^{* * *} \\
(0.419)\end{array}$ & $\begin{array}{l}-1.225 \\
(0.872)\end{array}$ & & $\begin{array}{c}-1.866^{* * *} \\
(0.449)\end{array}$ & $\begin{array}{l}-1.205 \\
(0.958)\end{array}$ \\
\hline
\end{tabular}


Performance Progressive

Performance Independence

Performance Left-Green

Performance Civic

Knowledge $\times$ perf. Soc. Dem.

Knowledge $\times$ perf. Progressive

Knowledge $\times$ perf. Independence

Knowledge $\times$ perf. Left-Green

Knowledge $\times$ perf. Civic

Constant

$\begin{array}{cc}2.055^{* * *} & 2.208 * * \\ (0.344) & (0.839) \\ 0.376 & 0.116 \\ (0.369) & (0.831)\end{array}$

(0.369) (0.831)

$-0.918 * \quad-0.715$

(0.375) (0.797)

$-0.376 \quad-1.536^{*}$

(0.302)

(0.689

$-0.415$

(0.374)

$-0.070$

(0.347)

0.160

(0.354)

$-0.105$

(0.356)

0.527

(0.280)
0.819* $\quad 1.381$

(0.373) (0.939)

$2.263 * * * \quad 2.485 *$

(0.430) (1.028)

$-1.296 * * \quad-1.583$

(0.410) (0.898)

$-0.493 \quad-0.741$

(0.330) (0.771)

$-0.301$

(0.401)

$-0.237$

(0.371)

$-0.062$

(0.414)

0.101

(0.389)

0.130

(0.301)

$5.194 * * * \quad 3.990 \quad 3.808 *$

$3.211 * *$

(1.117)
1.563

(1.412)
$-0.027$ (1.923) 
Table 2 (continued)

\begin{tabular}{|c|c|c|c|c|c|c|}
\hline \multirow{3}{*}{$\begin{array}{l}\text { Ref.: Vote Social } \\
\text { Democratic Alliance }\end{array}$} & \multicolumn{3}{|c|}{ Left-Green Movement } & \multicolumn{3}{|c|}{ Bright Future } \\
\hline & (1) & (2) & (3) & (1) & (2) & (3) \\
\hline & $\begin{array}{c}\text { B } \\
\text { (s.e.) }\end{array}$ & $\begin{array}{c}\text { B } \\
\text { (s.e.) }\end{array}$ & $\begin{array}{l}\text { B } \\
\text { (s.e.) }\end{array}$ & $\begin{array}{c}\text { B } \\
\text { (s.e.) }\end{array}$ & $\begin{array}{c}\text { B } \\
\text { (s.e.) }\end{array}$ & $\begin{array}{c}\text { B } \\
\text { (s.e.) }\end{array}$ \\
\hline Sex (ref.=male) & $\begin{array}{c}0.583 \\
(0.380)\end{array}$ & $\begin{array}{c}0.240 \\
(0.406)\end{array}$ & $\begin{array}{l}0.200 \\
(0.415)\end{array}$ & $\begin{array}{l}-0.317 \\
(0.391)\end{array}$ & $\begin{array}{l}-0.423 \\
(0.407)\end{array}$ & $\begin{array}{l}-0.430 \\
(0.414)\end{array}$ \\
\hline Age & $\begin{array}{l}-0.017 \\
(0.013)\end{array}$ & $\begin{array}{l}-0.017 \\
(0.013)\end{array}$ & $\begin{array}{l}-0.016 \\
(0.013)\end{array}$ & $\begin{array}{l}-0.032^{*} \\
(0.013)\end{array}$ & $\begin{array}{l}-0.028^{*} \\
(0.013)\end{array}$ & $\begin{array}{l}-0.029^{*} \\
(0.013)\end{array}$ \\
\hline Satisfaction democracy & $\begin{array}{l}-0.390 \\
(0.269)\end{array}$ & $\begin{array}{l}-0.403 \\
(0.313)\end{array}$ & $\begin{array}{l}-0.310 \\
(0.322)\end{array}$ & $\begin{array}{c}0.196 \\
(0.281)\end{array}$ & $\begin{array}{c}0.274 \\
(0.308)\end{array}$ & $\begin{array}{c}0.257 \\
(0.315)\end{array}$ \\
\hline Political interest & $\begin{array}{c}0.026 \\
(0.231)\end{array}$ & $\begin{array}{c}0.019 \\
(0.253)\end{array}$ & $\begin{array}{l}0.035 \\
(0.264)\end{array}$ & $\begin{array}{c}-0.509^{*} \\
(0.232)\end{array}$ & $\begin{array}{l}-0.515^{*} \\
(0.234)\end{array}$ & $\begin{array}{l}-0.514^{*} \\
(0.239)\end{array}$ \\
\hline Political knowledge & $\begin{array}{c}0.266 \\
(0.179)\end{array}$ & $\begin{array}{c}0.157 \\
(0.188)\end{array}$ & $\begin{array}{l}-0.309 \\
(0.816)\end{array}$ & $\begin{array}{c}0.357 \\
(0.186)\end{array}$ & $\begin{array}{c}0.286 \\
(0.187)\end{array}$ & $\begin{array}{c}0.797 \\
(0.671)\end{array}$ \\
\hline PID Soc. Dem. Alliance & $\begin{array}{c}-19.563 \\
(2467.576)\end{array}$ & $\begin{array}{c}-20.145 \\
(4345.264)\end{array}$ & $\begin{array}{c}-29.670 \\
(4.757 \mathrm{e}+05)\end{array}$ & $\begin{array}{l}-3.491 * * * \\
(1.040)\end{array}$ & $\begin{array}{l}-3.420^{* *} \\
(1.052)\end{array}$ & $\begin{array}{l}-3.536 * * * \\
(1.062)\end{array}$ \\
\hline \multirow[t]{2}{*}{ PID Progressive Party } & 0.234 & 0.127 & -0.160 & -0.573 & -0.423 & -0.500 \\
\hline & $(1446.021$ & \multicolumn{3}{|c|}{$(1243.930)(1.332 \mathrm{e}+05)(1792.555)$} & \multicolumn{2}{|c|}{$(1818.281)(1.948 \mathrm{e}+05)$} \\
\hline PID Independence Party & $\begin{array}{l}-0.577 \\
(1.260)\end{array}$ & $\begin{array}{l}-0.188 \\
(1.325)\end{array}$ & $\begin{array}{l}-0.215 \\
(1.420)\end{array}$ & $\begin{array}{l}-13.255 \\
(603.024)\end{array}$ & $\begin{array}{l}-13.500 \\
(606.552)\end{array}$ & $\begin{array}{c}-23.008 \\
(6.406 \mathrm{e}+04)\end{array}$ \\
\hline PID Left Green Movement & $\begin{array}{c}3.599 * * * \\
(1.050)\end{array}$ & $\begin{array}{l}3.117 * * \\
(1.065)\end{array}$ & $\begin{array}{l}3.077 * * \\
(1.077)\end{array}$ & $\begin{array}{c}0.712 \\
(1.450)\end{array}$ & $\begin{array}{c}0.882 \\
(1.457)\end{array}$ & $\begin{array}{c}0.895 \\
(1.466)\end{array}$ \\
\hline PID Bright Future & $\begin{array}{c}0.044 \\
(3.11 \mathrm{e}+05)\end{array}$ & $\begin{array}{c}1.388 \\
(8.896 \mathrm{e}+05)\end{array}$ & $\begin{array}{c}1.623 \\
(1.091 \mathrm{e}+08)\end{array}$ & $\begin{array}{c}26.458 \\
(2.171 \mathrm{e}+05)\end{array}$ & $\begin{array}{c}29.302 \\
(7.907 e+0\end{array}$ & $\begin{array}{c}38.573 \\
(1.015 \mathrm{e}+08)\end{array}$ \\
\hline Performance government & $\begin{array}{c}0.511 \\
(0.310)\end{array}$ & $\begin{array}{c}0.394 \\
(0.410)\end{array}$ & $\begin{array}{c}0.559 \\
(0.419)\end{array}$ & $\begin{array}{l}-0.505 \\
(0.301)\end{array}$ & $\begin{array}{l}-0.195 \\
(0.394)\end{array}$ & $\begin{array}{l}-0.204 \\
(0.402)\end{array}$ \\
\hline Performance Soc. Dem. & & $-1.308 * *$ & 0.226 & & -0.538 & 0.171 \\
\hline & & $(0.412)$ & $(0.997)$ & & $(0.426)$ & $(0.979)$ \\
\hline
\end{tabular}


Performance Progressive

Performance Independence

Performance Left-Green

Performance Civic

Knowledge $\times$ perf. Soc. Dem.

Knowledge $\times$ perf. Progressive

Knowledge $\times$ perf.

Independence

Knowledge $\times$ perf. Left-Green

Knowledge $\times$ perf. Civic

$$
-0.0
$$

(0.306) (0.791)

$-0.187 \quad-0.213$

(0.346) (0.810)

$1.764 * * * \quad 1.078$

(0.457) (0.997)

$0.390 \quad-1.171$

(0.295) (0.685)

$-0.715$

(0.416)

0.077

(0.343)

0.011

(0.347)

(0.346)

0.340

$-0.206$

(0.454)

(0.353)

$0.678 *$

0.375

(0.284)

Constant

$\begin{array}{ll}-0.695 & -1.404 \\ (1.210) & (1.472)\end{array}$

$-0.882$

$2.391 *$

$2.876^{*}$

1.803

(1.210) (1.472)

(2.182)

(1.160)

(1.286)

(1.911)

Note: Entries are log-odds coefficients, standard errors reported in parentheses. $\mathrm{N}=661$ in all models. Pseudo $R^{2}$ : Model 1: 0.451; Model 2: 0.559; Model 3: 0.567. Data: ICENES 2013. Significance levels:* $p$ $<0.05, * * p<0.01, * * * p<0.001$. 
Note the very large standard errors of the coefficients of party identification. One possible explanation would be multicollinearity, but a VIF-test showed no worrisome results (mean $\mathrm{VIF}=1.54)$. Hence, it is most likely due to the fact that, for some parties, there are only small proportions of respondents reporting to feel close to that party, making for cells with a very small number of observations in the data. To test whether this has any influence on the conclusions, the models were estimated excluding party identification, showing the same substantial results. The results are available upon request. Figure 1 displays the full effect of all interactions included in Model 3 of Table 2.

Figure 1: Effects of the coefficients of Model 3 in Table 2
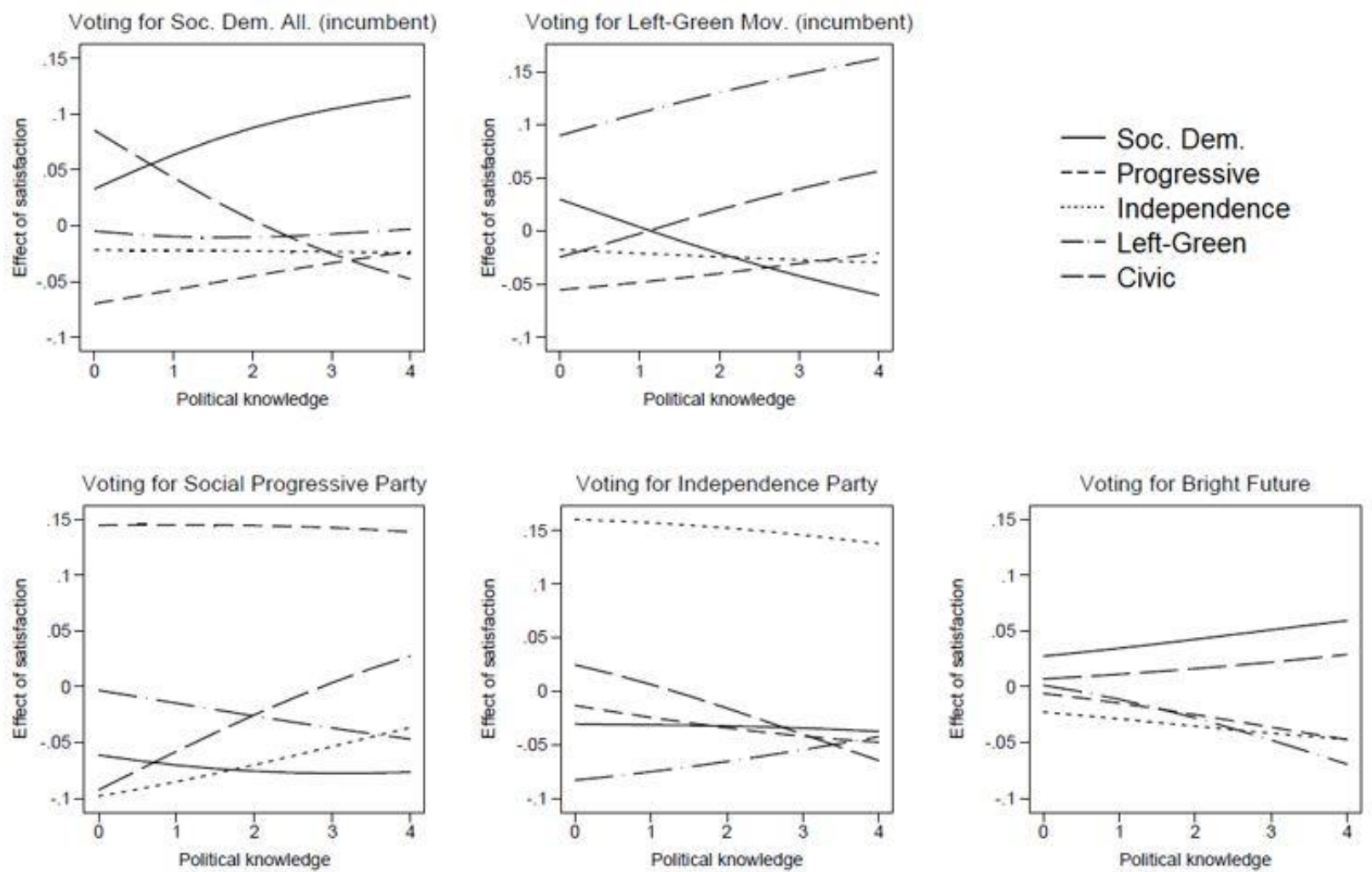


\section{Appendix C: Conditional logistic regression}

Next to the multinomial models reported in the main text, I also replicate the models of Stiers (forthcoming). As there are evaluations of every party available, the general effect of retrospective performance evaluations on the party level on the party choice, as well as the moderating effect of political knowledge, will be investigated by estimating fixedeffects conditional logit models. Following the models of Stiers (forthcoming), controls are added for party identification and the ideological distance to each party respectively. Then, the robustness of the results is tested by controlling for government satisfaction. Finally, to test whether there is a knowledge-gap in retrospective voting on the party level, an interaction between performance evaluations and political knowledge is included in the model as well. The variables that are included are the following:

- Party identification: First, respondents were asked: 'Many people consider themselves supporters of political parties while others do not feel solidarity with any party. Do you in general consider yourself as a supporter of any political party or organisation?'. Respondents could answer with “yes” or “no”. Those answering no were subsequently asked: 'Do you nevertheless feel somewhat closer to any party or organisation than to others?' Again, respondents could answer whether or not they feel closer to a party. Respondents answering "yes" on one of the two questions were subsequently asked 'what party is that?' Respondents receive code 1 as identifying with a certain party if they mention that party, and code 0 otherwise.

- Ideological distance: First, respondents were asked to position themselves on an ideological scale ranging from 0 (left) to 10 (right). Then, respondents were asked to position all parties on this scale as well. The ideological distance for each party is the 
absolute value of the difference between the respondent's position and the respondent's placement of this party.

- Performance evaluation parties: Respondents were told: 'Next questions are about the performance of all the political parties that were represented in Althingi in the last electoral term (from 2009 to 2013). How good or a bad job do you consider that each party did during that term?' Subsequently, all parties were probed in a random order, and respondents could indicate whether the performance of the party was 'very good', 'somewhat good', 'somewhat bad', or 'very bad'. The scale was reversed so that higher numbers denote a better performance evaluations.

- Party in government: An indicator of whether the party was in government before the election (code 1$)$ or not (code 0$)$.

- Performance evaluation of government: Answer to the question: 'How good or bad a job in general do you think the government of the Social Democratic Alliance and the Left Green Movement, that was in power from 2009 until 2013, has done while it was in power? Has it done a very good job? A good job? A bad job? A very bad job? The scale was reversed so that higher numbers denote a better performance evaluation.

- Political knowledge: The amount of correct answers on four factual questions. The questions were:

- Which of these persons was the Finance Minister before the recent election?

- What was the current unemployment rate in Iceland as of the end of March 2013? Was it...

- Which party came second in votes in the election to Althingi?

- Who is the current Secretary-General of the United Nations? 
For each question, respondents could choose from four answer-categories. Respondents refusing to answer and don't knows are coded as wrong answers.

Table 3: Descriptive statistics of the variables in the analyses

\begin{tabular}{lcccc}
\hline \hline Variable & Mean & Std. Dev. & Minimum & Maximum \\
\hline Party identification & 0.119 & 0.324 & 0 & 1 \\
Ideological distance & 2.628 & 1.839 & 0.151 & 8.400 \\
Performance party & 1.345 & 0.819 & 0 & 3 \\
Party in government & 0.505 & 0.500 & 0 & 1 \\
Performance & 1.447 & 0.826 & 0 & 3 \\
government & & & & \\
Political knowledge & 2.286 & 1.082 & 0 & 4 \\
\hline \hline
\end{tabular}

The results are summarised in Table 4. Note that the main effect of satisfaction with government and political knowledge cannot be included because they do not vary over the different options the voter can choose from. However, their effects can be modelled by including them in interaction with the government status of a party and the evaluations of the parties respectively. 
Table 4: Conditional logistic regression models predicting incumbent voting

\begin{tabular}{lccc}
\hline \hline & $(1)$ & $(1)$ & $(1)$ \\
& $\mathrm{B}$ & $\mathrm{B}$ & $\mathrm{B}$ \\
& $(\mathrm{s.e.})$ & $($ s.e. $)$ & $(\mathrm{s.e.})$ \\
\hline Party identification & $3.636^{* * *}$ & $3.574 * * *$ & $3.588^{* * *}$ \\
& $(0.298)$ & $(0.298)$ & $(0.300)$ \\
Ideological distance & $-0.365^{* * *}$ & $-0.342^{* * *}$ & $-0.343^{* * *}$ \\
& $(0.048)$ & $(0.049)$ & $(0.049)$ \\
Performance party & $1.702^{* * *}$ & $1.569 * * *$ & $1.348^{* * *}$ \\
& $(0.152)$ & $(0.158)$ & $(0.328)$ \\
Party in government & $-0.633^{* * *}$ & $-2.199 * * *$ & $-2.173 * * *$ \\
& $(0.144)$ & $(0.496)$ & $(0.497)$ \\
Party in government x performance government & & $0.899 * * *$ & $0.885^{* * *}$ \\
& & $(0.264)$ & $(0.264)$ \\
Political knowledge x performance party & & & 0.104 \\
& & & $(0.137)$ \\
\hline$N$ & & 2968 & 2968 \\
Pseudo- $R^{2}$ & 0.600 & 0.607 & 0.607 \\
\hline \hline
\end{tabular}

Note: Entries are log-odds coefficients, standard errors reported in parentheses. Data: ICENES 2013. Significance levels: $* p<0.05, * * p<0.01, * * * p<0.001$.

The results presented in Model 1 and Model 2 of Table 4 are in line with the results of Stiers (forthcoming): Retrospective performance evaluations have a strong effect on the party choice, and this result holds controlling for the evaluation of government performance. Furthermore, the latter also has an independent significant impact on the vote for parties in government. To interpret the results more intuitively, their effects are displayed in Figure 2.

The results in Figure 2 show that voters are more likely to vote for a party with which they identify, that is ideologically close to them, and that government evaluations influence incumbent voting. Above all, however, they show the strong impact of evaluations of the parties on the vote, and although it is difficult to compare effect sizes in logistic models and over variables with different scales, the effect is clearly substantive in size. 
Finally, it is tested whether political knowledge moderates retrospective voting on the level of political parties - as it has been shown to do on the level of the government. To do so, an interaction between political knowledge and performance evaluations is included in Model 3 in Table 4, and this shows whether performance evaluations matter more in the vote choice process for higher knowledgeable voters. As can be seen in the Table, although the coefficient is positive, it does not reach a conventional level of significance. Hence, the conclusion seems to be that - at least in Iceland - there is no knowledge-gap in retrospective voting on the level of parties; all parties are evaluated and held accountable by all voters.

Figure 2: Effects of the coefficients of Model 2 in Table 4.
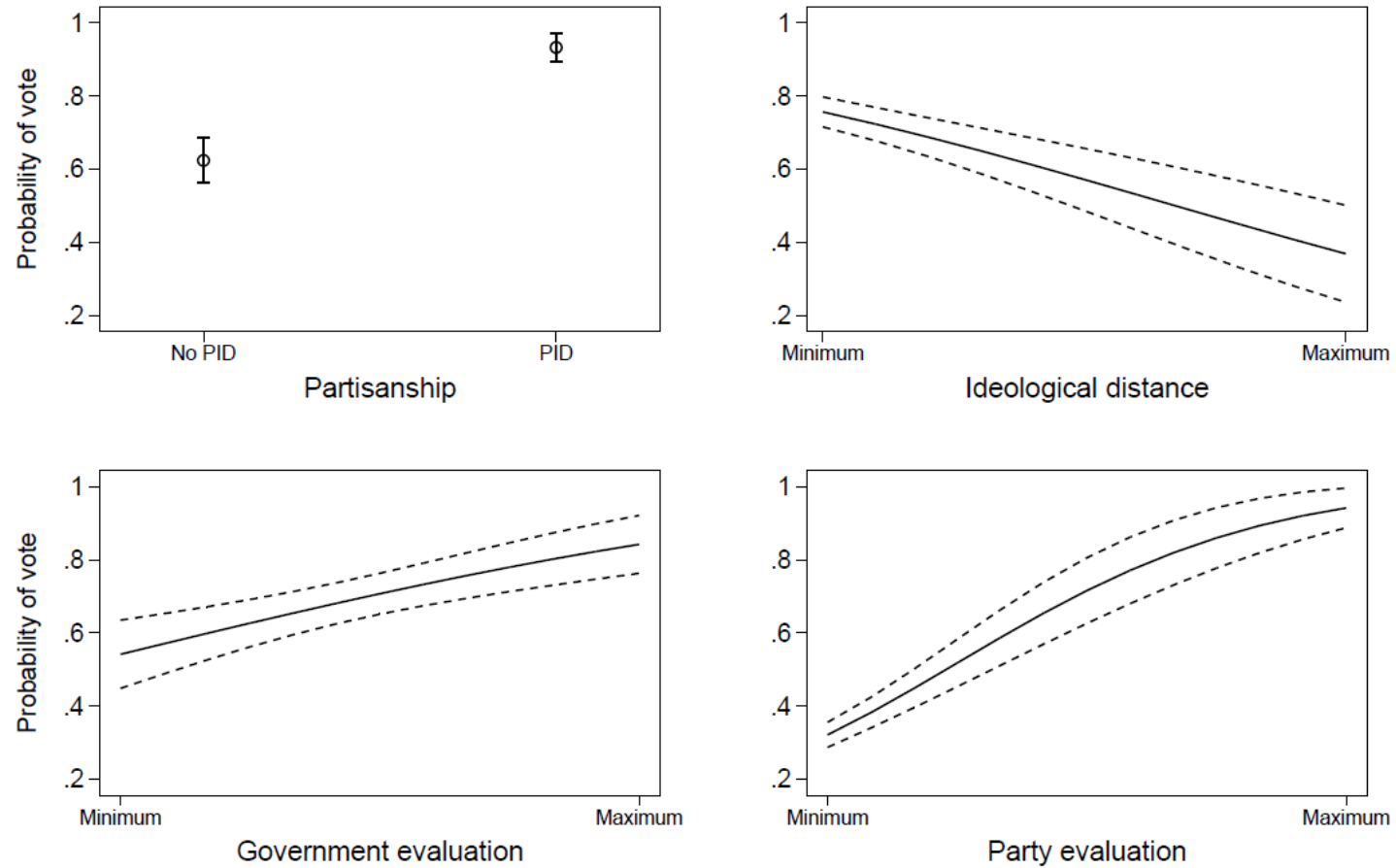

Note: the figure shows the probability of voting for a party at different levels of the variables based on the results presented in Model 2 in Table 4. 